\title{
Identification of Bacillus Strains Using the API System
}

\author{
By N. A. LOGAN† AND R. C. W. BERKELEY* \\ Department of Microbiology, The Medical School, University of Bristol, Bristol BS8 ITD, UK
}

(Received 14 December 1983; revised 23 March 1984)

\begin{abstract}
A system is described for the rapid and accurate identification of Bacillus isolates using a matrix of results from tests in the API $20 \mathrm{E}$ and API 50CHB strips and from supplementary tests. API System tests have been shown to be more reproducible than the classical tests. A taxonomy based upon API tests is in good agreement with those obtained by other methods. The results matrix can also be used in computer assisted identification.
\end{abstract}

\section{INTRODUCTION}

Although diagnostic keys and tables for Bacillus have been available for a long time (Gibson \& Topping, 1938; Smith et al., 1946; Cowan \& Steel, 1965), the identification of these organisms is still considered to be complicated (Green, 1975; King \& Phillips, 1978) and in many laboratories is taken no further than 'aerobic spore-forming rod', or 'Bacillus species'. It is clear, however, from the numerous papers published and the large number of strains received for identification in this laboratory, that Bacillus species are of increasing importance in industry and medicine and that diagnosis to the species level is highly desirable in many instances.

The prevailing neglect of Bacillus identification may be attributed to two factors. Firstly, the diagnostic tests used; many of the classical tests for Bacillus described by Smith et al. (1946, 1952) and Gordon et al. (1973) require special media. These are very time consuming and expensive to prepare and many have short shelf lives resulting in considerable wastage if their use is infrequent. The requirement for media containing unusual ingredients increases the familiar problems of test standardization (Sneath, 1974; Sneath \& Collins, 1974); inconsistent results may be obtained in consequence. Several tests take $14 \mathrm{~d}$ or more from pure culture to final reading and this is too long for many diagnosticians to wait. Any new scheme for Bacillus identification should therefore use widely available and standardized materials for performing a good number of rapid tests which give reproducible results.

The second factor leading to neglect of Bacillus identification is the character of the genus. Bacillus is an unusually wide taxon which contains most aerobic endospore-forming rods. In terms of DNA base ratios it is the equivalent of some bacterial families (Priest, 1981). Furthermore, some species are ill-defined, existing with closely related species as complexes or spectra in which the boundary of a particular species is difficult or impossible to identify. Even in well established species there is considerable variation between strains. Thus classical test schemes using few characters often do not permit identification of atypical and intermediate strains and in spite of the excellent work of Gordon and her colleagues (Smith et al., 1952; Gordon, 1973; Gordon et al., 1973), as well as others, it is widely agreed that there is considerable room for improvement in the taxonomy of the genus and that a study of new isolates, particularly, is important.

With these considerations in mind, work was started to produce a system for the ready and rapid identification of Bacillus strains. A study of a collection of 600 strains, of which 91 were unnamed, using 119 API and 20 supplementary tests, has been carried out (Logan \& Berkeley, 1981). A development of this work (written later but published earlier), based on the 80 tests

\footnotetext{
$\dagger$ Present address: Department of Biological Sciences, Glasgow College of Technology, Cowcaddens Road, Glasgow G4 0BA, UK. 
showing greatest reproducibility and discriminatory value, was described by Logan (1980). Despite considerable between-strain variation in many species this study showed that the majority of taxa are quite distinct. API materials used in these trials included the $20 \mathrm{E}, 50 \mathrm{E}$ (both designed for identification of members of the Enterobacteriaceae), API ZYM and four other, non-commercially available, enzyme test strips (Logan, 1980). The 50E has now been superseded by the $50 \mathrm{CH}$.

In this paper a development of these studies is described. It uses tests in the API 50CHB (Bacillus) system in place of those from the $50 \mathrm{E}$, together with those used previously from the $20 \mathrm{E}$, and a small number of morphological and supplementary characters. The enzyme strips were not used as they contribute little to identification (Logan, 1980).

\section{METHODS}

Strains and growth conditions. One thousand and seventy-five strains from culture collections, industrial, medical and veterinary specimens and from the natural environment were studied. All were checked, on inclusion in the collection, for purity, medium requirements and growth temperatures. The strains were representative of the whole genus, but the fastidious insect pathogens, $B$. larvae, $B$. lentimorbus and $B$. popilliae, and species requiring a very high or very low $\mathrm{pH}$ for growth ( $B$. alcalophilus and $B$. acidocaldarius respectively) were omitted from this study. Except for these, type strains were included for all species on the Approved Lists of Bacterial Names (Skerman et al., 1980). The numbers of representatives of each species are shown in Table 1.

Strains were held at $4{ }^{\circ} \mathrm{C}$, in the dark, on slopes of nutrient agar (Difco) containing $5 \mathrm{mg} \mathrm{MnSO} 4.4 \mathrm{H}_{2} \mathrm{O}^{-1}$ (NA $+\mathrm{Mn}^{2+}$ ) in order to enhance sporulation (Deutsche Sammlung von Mikroorganismen, 1977) and strains were allowed to sporulate prior to storage. For morphological studies strains were grown at $30^{\circ} \mathrm{C}$ for $48 \mathrm{~h}$ (or $20^{\circ} \mathrm{C}$ for $96 \mathrm{~h}$ for psychrophilic strains, $37^{\circ} \mathrm{C}$ for $48 \mathrm{~h}$ for $\mathrm{B}$. coagulans, and $55^{\circ} \mathrm{C}$ for $24 \mathrm{~h}$ for thermophilic strains) on plates of NA $+\mathrm{Mn}^{2+}$. For API tests strains were grown overnight (or, for psychrophiles, $48 \mathrm{~h}$ ) on plates of nutrient agar (Difco) (NA) at the appropriate temperature. Certain strains would not grow satisfactorily on NA or NA $+\mathrm{Mn}^{2+}$ and special media had to be used, as follows.

Allantoin Mineral Medium (Deutsche Sammlung von Mikroorganismen, 1977) for B. fastidiosus contained $\left(\mathrm{gl}^{-1}\right): \mathrm{K}_{2} \mathrm{HPO}_{4}, 0.8 ; \quad \mathrm{KH}_{2} \mathrm{PO}_{4}, 0.2 ; \mathrm{MgSO}_{4} .7 \mathrm{H}_{2} \mathrm{O}, 0.5 ; \mathrm{CaCl}_{2} .2 \mathrm{H}_{2} \mathrm{O}, 0.05 ; \quad \mathrm{FeSO}_{4} .7 \mathrm{H}_{2} \mathrm{O}, 0.01 ;$ $\mathrm{MnSO}_{4} .4 \mathrm{H}_{2} \mathrm{O}, 0.001$ (increased to 0.005 for sporulation); allantoin (Sigma), 20; agar, 15; at pH 6.8.

'Bacillus racemilacticus' Medium (Deutsche Sammlung von Mikroorganismen, 1977) for ' $B$ laevolacticus' and ' $B$. racemilacticus' contained $\left(\mathrm{g} \mathrm{l}^{-1}\right)$ : glucose, 5 ; peptone 5 ; yeast extract, 5 ; $\mathrm{CaCO}_{3}, 5$; agar, 15 ; at $\mathrm{pH} 6.8$. For sporulation, $5 \mathrm{mg} \mathrm{MnSO}_{4} .4 \mathrm{H}_{2} \mathrm{Ol}^{-1}$ was added prior to autoclaving.

Bacillus pasteurii medium (Gibson \& Gordon, 1974) was prepared by adding $10 \mathrm{~g} \mathrm{NH}_{4} \mathrm{Cl}^{-1}$ to NA or NA + $\mathrm{Mn}^{2+}$ and adjusting the medium to $\mathrm{pH} 9$ prior to autoclaving.

A strain that will grow only on such special media is unlikely to be isolated accidentally and its growth requirements will give some indication of its identity. In such cases the API and morphological tests serve principally to confirm or challenge this first identification.

Morphological and supplementary tests. Vegetative cell morphology observations were made on cultures grown overnight, or for such longer time as was necessary to obtain visible growth, on $\mathrm{NA}+\mathrm{Mn}^{2+}$ or another suitable sporulation medium, at the appropriate temperature. Organisms were examined at $1000 \times$ magnification, using phase contrast microscopy, for shape of cells, presence of chains, and for a foamy or vacuolate appearance of the cytoplasm. Widths of cells were measured using a Vickers-AEI image splitting eyepiece (Quesnel, 1971).

To determine motility, strains were grown on slopes of NA and after $6 \mathrm{~h}$, or as soon as growth appeared thereafter, a loopful of the liquid at the base of the slope was examined at $1000 \times$ magnification, by phase contrast microscopy.

It was occasionally possible to observe spores in slides prepared from cultures grown overnight on a suitable sporulation medium at the appropriate temperature, but most strains required incubation for $2 \mathrm{~d}$, occasionally longer, before spore and sporangial morphology could be observed. Cultures were examined for shape of spores, their position in the sporangia, distension of the sporangia by mature spores, and for the presence of parasporal bodies and crystals. Three categories of spore shape were used, round, ellipsoidal and cylindrical; oval spores were recorded as both round and ellipsoidal, kidney shaped spores as ellipsoidal, and banana shaped spores as cylindrical. Intermediate cases were recorded as positive for both of the shapes that they lay between. There were three categories of spore position: terminal, subterminal and central or paracentral. Spores in several different positions might be observed in one culture. Sporangial swelling was only recorded as positive if the distension was substantial.

API tests. Tests in the API 20E strip and the API 50CHB (Bacillus) strips (API Laboratory Products, Basingstoke, Hants., UK) were used: 12 tests in the API 20E strip and 49 tests in the API 50CHB strips. The latter contain carbohydrate substrates for the detection of assimilation or acid production (according to the suspension 
medium used) and have 37 substrates in common with the obsolete API 50E gallery. The tests are listed in Table 1.

Strains were grown on plates of NA, or another appropriate medium, overnight or, for psychrophiles, $48 \mathrm{~h}$. Growth was harvested in $2 \mathrm{ml}$ sterile normal saline and the suspension so produced was used to prepare two further suspensions : (i) for API 20E strip in $4 \mathrm{ml}$ sterile normal saline to correspond to tube no. 3 of the McFarland

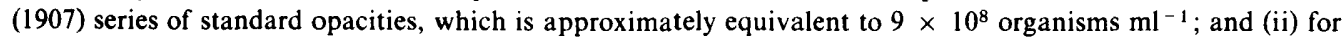
API 50CHB strips in $10 \mathrm{ml}$ of API 50CHEB (Enterobacteriaceae/Bacillus) medium, which contains $\left(\mathrm{g} \mathrm{l}^{-1}\right.$ ) $\left(\mathrm{NH}_{4}\right)_{2} \mathrm{SO}_{4}, 2$; yeast extract, $0 \cdot 5$; tryptone, 1; phenol red, 0.18; with mineral base of Cohen-Bazire et al. (1957) $10 \mathrm{ml}$; in a phosphate buffer of pH 7.5 after sterilization, to correspond to tube no. 3 of the McFarland scale. Only the first twelve tests of the API 20E strip were inoculated, the last eight being carbohydrate tests duplicated in the API 50CHB strips.

Strips were incubated at $30^{\circ} \mathrm{C}$ for $48 \mathrm{~h}$ and read at 24 and $48 \mathrm{~h}$ or, for psychrophiles, at $20^{\circ} \mathrm{C}$ for $96 \mathrm{~h}$, reading at 48 and $96 \mathrm{~h}$ or, for thermophiles, at $55^{\circ} \mathrm{C}$ for $24 \mathrm{~h}$ reading at about 12 and $24 \mathrm{~h}$. The API 50CHB strips were tilted at approximately $5^{\circ}$, bases of tubes uppermost, during incubation in order to trap any gas evolved.

Results were scored according to the manufacturer's instructions. A test scoring positive at either reading time was considered positive. Occasionally, tests appeared positive at the first reading but reverted to negative by the final reading; in the API 50CH gallery this was due to the production of large quantities of alkali which masked the acid production (alkaline reversion).

The tubes of the API 50CHB strips were examined for gas bubbles

Identification by computer. Logan (1980) and Logan \& Berkeley (1981) computed similarity coefficients using the general similarity coefficient $\left(S_{G}\right)$ of Gower (1971). Clusters were formed by unweighted pair-group average linkage analysis (Sokal \& Michener, 1958) and the results of several runs were illustrated by phenograms. These served as a basis for breaking the set of strains into groups of manageable size for principal co-ordinate analysis. The method of identification was that of Ross (1975) in which similarity coefficients are used. This is a simultaneous method and represents a development of the diagnostic table. Gower (1968) developed a technique for adding points to a principal co-ordinate analysis using the similarity coefficients between the new unit and each of the reference units; this useful supplement to identification by similarity coefficients enables the distinction between intermediate and outlying strains when working with groups.

All these facilities are available in the CLASP program (written by G. J. S. Ross, F. B. Lauckner and D. Hawkins, Rothamsted Experimental Station, Harpenden, Herts., UK) which was run on the ICL 4-75 computer at the University of Bristol.

All 475 new strains and the 91 unnamed strains from the studies of Logan (1980) and Logan \& Berkeley (1981) were identified using the set of 509 named strains for reference.

\section{RESULTS AND DISCUSSION}

The results of the tests for the 1075 Bacillus strains are expressed as percentages of positive results for each species or group of strains in Table 1.

The information provided by certain tests is, however, of no value in identification because the results given are always negative. These tests are as follows: in the API 20E strip - lysine decarboxylase, ornithine decarboxylase and tryptophan deaminase; and in the API 50CHB strips - erythritol, L-xylose, and L-arabitol. In addition, D-fucose and 2-ketogluconate appear to be of little value. This is a surprisingly small number of redundant tests considering that the systems were originally designed for the identification of Enterobacteriaceae and other Gramnegative rods. Several of the remaining tests appear to be of only moderate value because they merely support the separation achieved using tests of high discriminatory value; such support is, however, valuable in many cases because of the high within-species variation encountered in several species.

For several species, fewer than ten strains were available for study and in these instances the results in Table 1 are of reduced value for identification. In 25 species or groups, however, large numbers of strains were available and the results are considered to give an adequate indication of within-species variation (Sneath, 1978a; Gordon, 1981) for each test.

The results shown in Table 1 are most conveniently discussed by considering each species or group separately.

\section{Bacillus cereus group}

The positions of $B$. mycoides and $B$. thuringiensis, as species distinct from $B$. cereus, are not clear. Logan (1980) and Logan \& Berkeley (1981) were unable to separate these three species. It can be seen from Table 1 that there are few differential tests available other than the familiar 
Table 1. Percentage positive results for Bacillus species using morphological, supplementary, API $20 E$ and API 50CHB tests

The table shows, for each species or group, the percentage of strains studied giving positive reactions in each test. Negative results (i.e. $0 \%$ positive) have been omitted for clarity.

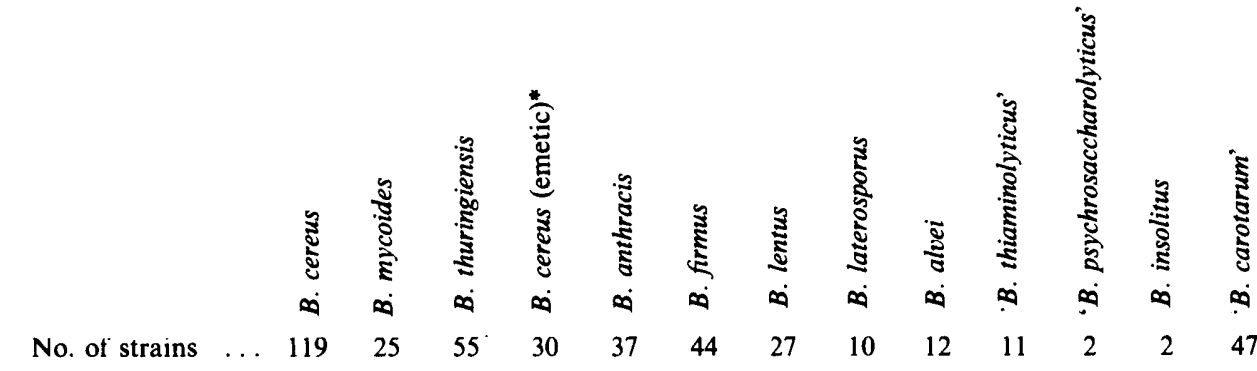

\section{Morphological and \\ supplementary tests}

$\begin{array}{lrrrrrrrrrrrrr}\text { 1. Cell width }(\mu \mathrm{m}) \ddagger & 1 \cdot 4 & 1 \cdot 3 & 1 \cdot 4 & 1 \cdot 4 & 1 \cdot 3 & 0 \cdot 8 & 0 \cdot 8 & 0.9 & 0 \cdot 8 & 0 \cdot 7 & 1 \cdot 0 & 0 \cdot 9 & 1 \cdot 1 \\ \text { 2. Chains of cells } & 96 & 100 & 100 & 100 & 100 & 29 & 70 & & 25 & & & 50 & 100 \\ \text { 3. Motility } & 96 & & 100 & 100 & & 100 & 100 & 100 & 100 & 100 & 100 & 100 & 42 \\ \text { 4. Spores round } & & & & & & & 15 & & & & & 50 & \\ \text { 5. Spores ellipsoidal } & 100 & 100 & 100 & 100 & 100 & 100 & 96 & 100 & 100 & 100 & 100 & 50 & 91 \\ \text { 6. Spores cylindrical } & 22 & & 20 & & & 29 & & & 17 & & 50 & 26 \\ \text { 7. Spores central/paracentral } & 70 & 84 & 6 & 30 & & 75 & 52 & 100 & 58 & & 100 & 100 & 62 \\ \text { 8. Spores subterminal } & 100 & 100 & 100 & 100 & 100 & 100 & 100 & 90 & 100 & 100 & 100 & 100 & 86 \\ \text { 9. Spores terminal } & & & & & & 3 & & & & & 50 & \\ \text { 10. Sporangia swollen } & & & & & & 51 & 30 & 100 & 92 & 91 & 100 & \\ \text { 11. Parasporal bodies } & & & & & & & & 100 & & & & \end{array}$

11. Parasporal bodies

12. Crystalline inclusions

13. Vacuoles

14. Gas from carbohydrates

$\begin{array}{rrrrr}83 & 100 & 100 & 100 & 100\end{array}$

API 20 E tests

15. ONPG

16. $\mathrm{ADH}$

17. LDC

18. ODC

19. Citrate (Simmons')

20. $\mathrm{H}_{2} \mathrm{~S}$

21. Urease

22. TDA

23. Indole

24. V-P

25. Gelatin

26. Nitrate API 50CHB tests

27. Glycerol

28. Erythritol

29. D-Arabinose

30. L-Arabinose

31. Ribose

32. D-Xylose

33. L-Xylose

34. Adonitol

35. $\beta$-Methylxyloside

36. Galactose

37. D-Glucose

38. D-Fructose

39. D-Mannose

40. L-Sorbose

41. Rhamnose

42. Dulcitol

43. Inositol

44. Mannitol

$\begin{array}{rrrr}60 & 32 & & \\ & 36 & 87 & 17 \\ 86 & 60 & 93 & 100\end{array}$

$23 \quad 89$

$42 \quad 100$

$100 \quad 100$

2

$$
\begin{array}{lll}
22 & 20 & 13
\end{array}
$$

$34 \quad 15 \quad 50$

100
50
$50 \quad 91$

$100 \quad 36$

30

50

$100 \quad 100$

$\begin{array}{rrrrrrrrrrrr}92 & 92 & 98 & 100 & 100 & 84 & 55 & 100 & 92 & 27 & 100 & 91\end{array}$

$\begin{array}{rrrrrrrrrrrrr}100 & 100 & 100 & 100 & 70 & 95 & 44 & 100 & 100 & 100 & 50 & & 76 \\ 80 & 76 & 92 & 87 & 100 & 50 & 15 & 90 & & 18 & & 50 & 66\end{array}$

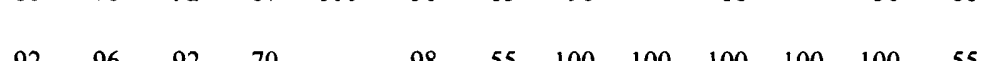

$\begin{array}{llllllllllll}92 & 96 & 92 & 70 & 98 & 55 & 100 & 100 & 100 & 100 & 100 & 55\end{array}$

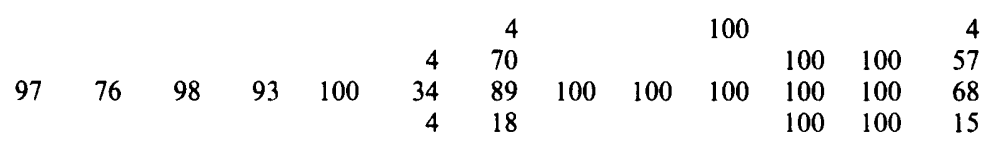

$\begin{array}{rrrrrrrrrrrrrr} & & & & & & & & 100 & 9 & & \\ 6 & 32 & & 6 & & 11 & 33 & & & & & 50 & \\ 100 & 100 & 100 & 100 & 100 & 100 & 100 & 100 & 100 & 100 & 100 & 100 & 98 \\ 98 & 84 & 100 & 100 & 59 & 52 & 100 & 100 & & 100 & 100 & 100 & 98 \\ & 8 & 41 & 3 & & 23 & 96 & 100 & 42 & 100 & 100 & & \end{array}$

$4 \quad 3$

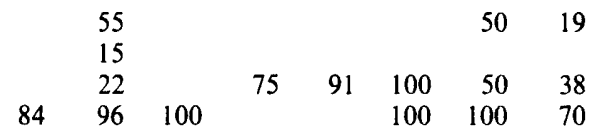




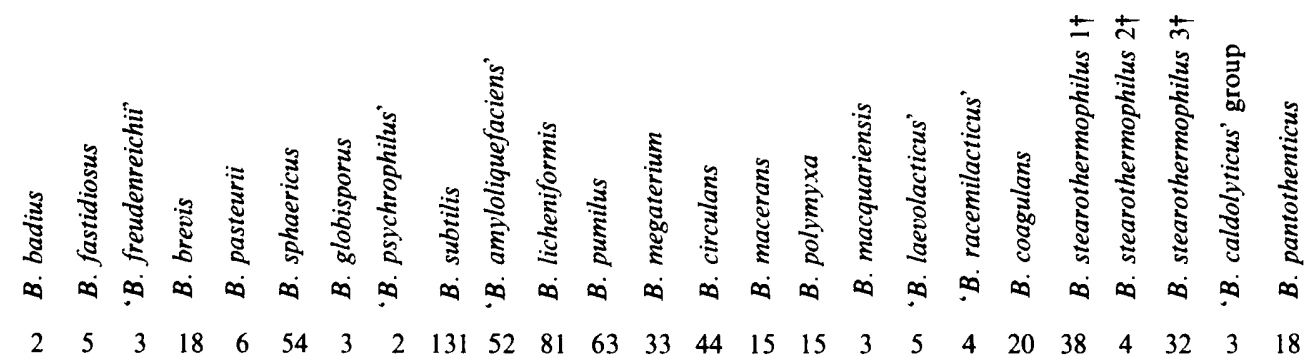

Tests

$\begin{array}{llllllllllllllllllllllllll}1 . & 0.9 & 1.3 & 0.9 & 0.9 & 0.7 & 1.0 & 0.9 & 0.9 & 0.8 & 0.8 & 0.8 & 0.7 & 1.5 & 0.8 & 0.7 & 0.9 & 0.6 & 0.7 & 0.7 & 0.8 & 0.8 & 0.7 & 0.9 & 0.8 & 0.6\end{array}$

2. $\quad \begin{array}{lllllllllllllllllllll}0 & 100 & 100 & 5 & 100 & 33 & 50 & 22 & 84 & 80 & 5 & 97 & 23 & 7 & 13 & 20 & 50 & 35 & 66 & 40 & 83\end{array}$

3. $100100100100100100100100 \quad 95100100100 \quad 97100100100100 \quad 40100100100100100100100$

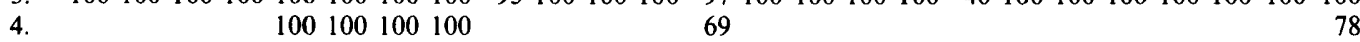

5. $100100100100 \quad 20 \quad 100100100 \quad 61100100100100100100100100 \quad 87100100100 \quad 78$

6. $\quad \begin{array}{llllllllll} & 8 & 20 & 89 & 20 & 7 & 7 & 57 & 9\end{array}$

$\begin{array}{llllllllllllll}7.50 & 80 & 100 & 81 & 40 & 7 & 49 & 40 & 40 & 29 & 40 & 10 & 75 & 3\end{array}$

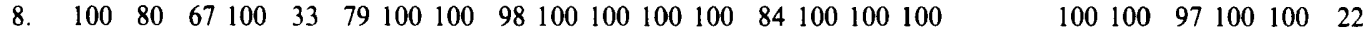

$\begin{array}{llllllllllllllllllll}9 . & 50 & 20 & 100 & 74 & 67 & 100 & 15 & 36 & 12 & 45 & 33 & 100 & 100 & 100 & 55 & 39 & 53 & 100 & 100\end{array}$

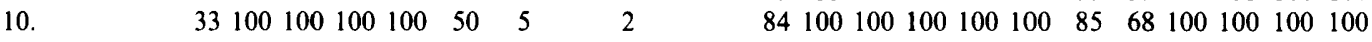

11.

12.

13.

14.

90

100100

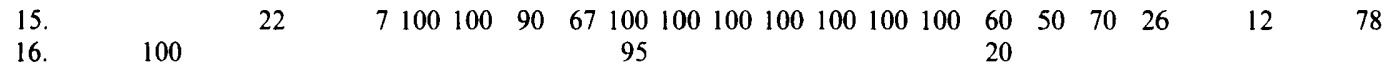

17.

18.

19. $1 \begin{array}{llllllllllll}100 & 80 & 33 & 44 & 85 & 100 & 98 & 92 & 99 & 89 & 85 & 4\end{array}$

20.

21.

22.

$\begin{array}{llllll}100 \quad 100 & 100 & 65 & 100 & 100 & 16\end{array}$

2025

23.

24

25. 100

26.

100

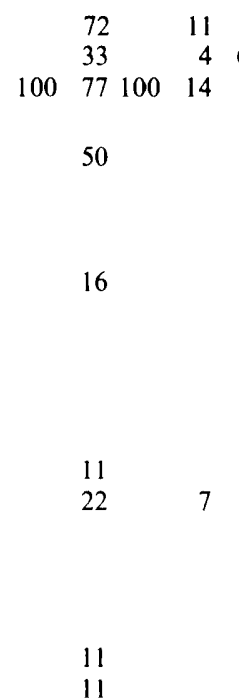

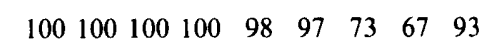

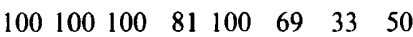
$\begin{array}{lllllllllll}67 & 100 & 100 & 100 & 100 & 98 & 100 & 38 & 40 & 93\end{array}$

20

$\begin{array}{llllll}30 & 95 & 100 & 100 & 100 & 94\end{array}$

27.

28.

29.

30.

31 .

32.

33.

34.

35.

36.

37.

38.

39 .

40.

41.

42.

43.

44. $\begin{array}{llllllll}100 & 95 & 88 & 96 & 15 & 13 & 47 & 100\end{array}$

20

$\begin{array}{lll}60 & 25 \quad 16\end{array}$

50

$\begin{array}{llllllll}97 & 96 & 100 & 98 & 100 & 86 & 100 & 100\end{array}$

$\begin{array}{lllllll}80 & 100 & 100 & 100 & 100 \quad 97 & 100 & 100\end{array}$

$$
\begin{aligned}
& \begin{array}{lllll}
23 & 93 & 7 & 25 & 10
\end{array} \\
& \begin{array}{lllllllllllll}
98 & 82 & 100 & 98 & 97 & 91 & 100 & 100 & 100 & 75 & 71 & 25 & 9
\end{array}
\end{aligned}
$$

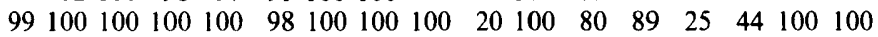

$$
\begin{aligned}
& \begin{array}{lllllllllllll}
89 & 71 & 99 & 98 & 91 & 98 & 100 & 100 & 100 & 100 & 70 & 66 & 75
\end{array}
\end{aligned}
$$

$$
\begin{array}{llll}
93100100100 & 3 & 50
\end{array}
$$

$\begin{array}{lllllllllllllllll}30 & 44 & 100 & 100 & 97 & 100 & 100 & 100 & 100 & 100 & 100 & 95 & 60 & 50 & 84 & 100 & 100\end{array}$

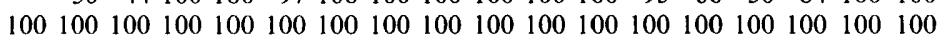

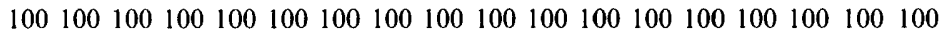
$\begin{array}{lllllllllllllllll}94 & 63 & 99 & 97 & 15 & 98 & 100 & 100 & 33 & 100 & 100 & 95 & 89 & 75 & 94 & 100 & 100\end{array}$ $\begin{array}{lllllllll}2 & 7 & 5 & 100 & 75 & 5 & 16 & 25 & 62\end{array}$

$\begin{array}{lllllllllllll}2 & 83 & 5 & 3 & 45 & 100 & 33 & 60 & 50 & 50 & 8 & 100\end{array}$

$\begin{array}{rrrrrrrrrrrr}95 & 86 & 76 & 28 & 100 & 41 & 40 & 40 & 26 & 75\end{array}$

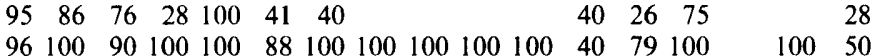




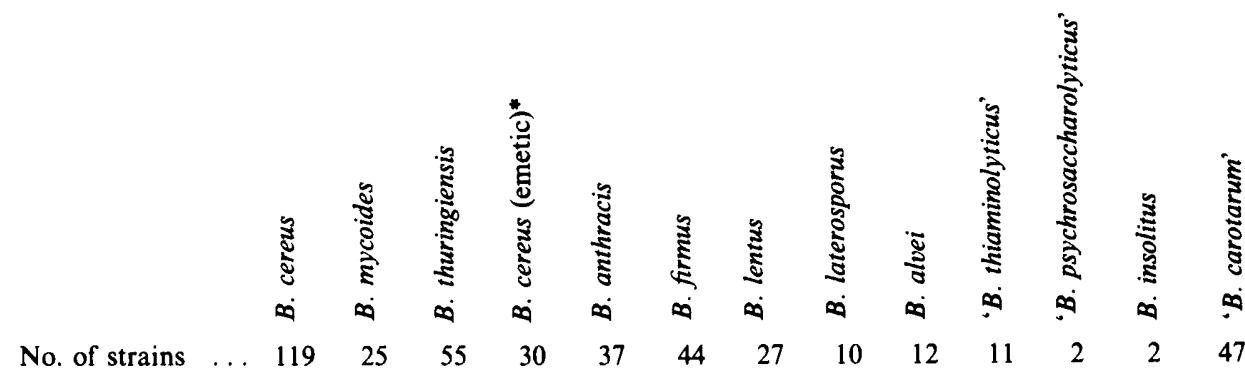

\section{API 50CHB tests (continued)}

45. Sorbitol

46. $\alpha$-Methyl-D-mannoside

47. $\alpha$-Methyl-D-glucoside

48. $N$-Acetylglucosamine

49. Amygdalin

50. Arbutin

51. Aesculin

52. Salicin

53. Cellobiose

54. Maltose

55. Lactose

56. Melibiose

57. Sucrose

58. Trehalose

59. Inulin

60. Melezitose

61. D-Raffinose

62. Starch

63. Glycogen

64. Xylitol

65. $\beta$-Gentiobiose

66. D-Turanose

67. D-Lyxose

68. D-Tagatose

69. D-Fucose

70. L-Fucose

71. D-Arabitol

72. L-Arabitol

73. Gluconate

74. 2-Ketogluconate

75. 5-Ketogluconate

\begin{tabular}{|c|c|c|c|c|c|c|c|c|c|c|c|c|}
\hline & & & & & 7 & 52 & & & & 50 & 50 & 21 \\
\hline & & & & & 2 & 15 & & & 91 & & 50 & \\
\hline 2 & 12 & 4 & & 3 & 2 & 52 & & 67 & 100 & 100 & 100 & \\
\hline 99 & 100 & 100 & 100 & 100 & 88 & 92 & 100 & 100 & 100 & 100 & 100 & 47 \\
\hline 8 & 24 & 2 & & & & 70 & 70 & 50 & 100 & 100 & 100 & 4 \\
\hline 91 & 84 & 100 & 60 & 32 & 13 & 81 & 100 & 67 & 100 & 100 & 100 & 13 \\
\hline 100 & 100 & 98 & 100 & 97 & 73 & 100 & 100 & 100 & 100 & 100 & 100 & 34 \\
\hline 87 & 80 & 83 & & & 13 & 78 & 100 & 42 & 100 & 100 & 100 & 19 \\
\hline 84 & 60 & 72 & 43 & & 7 & 81 & 90 & 50 & 91 & 100 & 100 & 81 \\
\hline 98 & 100 & 100 & 100 & 100 & 100 & 100 & 100 & 100 & 100 & 100 & 100 & 62 \\
\hline 8 & 8 & & & & 2 & 67 & & 25 & 91 & 100 & 50 & 2 \\
\hline & & & & & 2 & 78 & & 50 & 100 & 100 & 50 & 4 \\
\hline 47 & 64 & 55 & 83 & 100 & 91 & 100 & & 75 & 100 & 100 & 100 & 68 \\
\hline 98 & 92 & 100 & 100 & 100 & 75 & 89 & 100 & 58 & 100 & 100 & 50 & 89 \\
\hline & & & & & 7 & 11 & & & & & 50 & 40 \\
\hline 1 & & 4 & & & 2 & 48 & & 17 & 100 & & 50 & 2 \\
\hline & & 1 & & & 7 & 89 & & 50 & 100 & 100 & 50 & 42 \\
\hline 96 & 100 & 94 & 6 & 97 & 91 & 100 & 50 & 100 & 100 & 100 & 50 & 36 \\
\hline 92 & 100 & 92 & 10 & 92 & 54 & $\begin{array}{l}70 \\
11\end{array}$ & & 67 & 91 & 100 & 50 & 36 \\
\hline 18 & 3 & 4 & & & 7 & 63 & 90 & 83 & 100 & 100 & 100 & 15 \\
\hline 15 & 24 & 11 & 6 & 3 & 13 & 63 & & 67 & 100 & 100 & 100 & 2 \\
\hline & & & & & & 7 & & & & & 50 & \\
\hline & & & & & 2 & 15 & & & & & 50 & \\
\hline & & 2 & 3 & & & 4 & & 8 & 100 & & & 17 \\
\hline & & & & & 4 & 15 & & & 9 & & 50 & \\
\hline 29 & 12 & 6 & 40 & 3 & & 26 & & 8 & 100 & 50 & & \\
\hline & & & & & & 4 & & 17 & 100 & & & \\
\hline
\end{tabular}

rhizoid growth of $B$. mycoides and its lack of motility, and the pathogenicity for insects of $B$. thuringiensis and its production of crystalline inclusions. The results suggest that $B$. mycoides and $B$. thuringiensis should be considered as varieties of $B$. cereus.

Bacillus cereus strains of serotypes 1, 3, 5 and 8 (which include strains isolated in connection with outbreaks of emetic type food poisoning: Gilbert \& Parry, 1977; Gilbert et al., 1981; Taylor $\&$ Gilbert, 1975) gave characteristic results which enable their separation from other members of the B. cereus group (Logan et al., 1979); they are listed as B. cereus (emetic) in Table 1.

The 37 strains of $B$. anthracis comprised five avirulent, six low virulence, 23 virulent and three strains of unknown virulence; it is not possible to distinguish between these using API tests. 


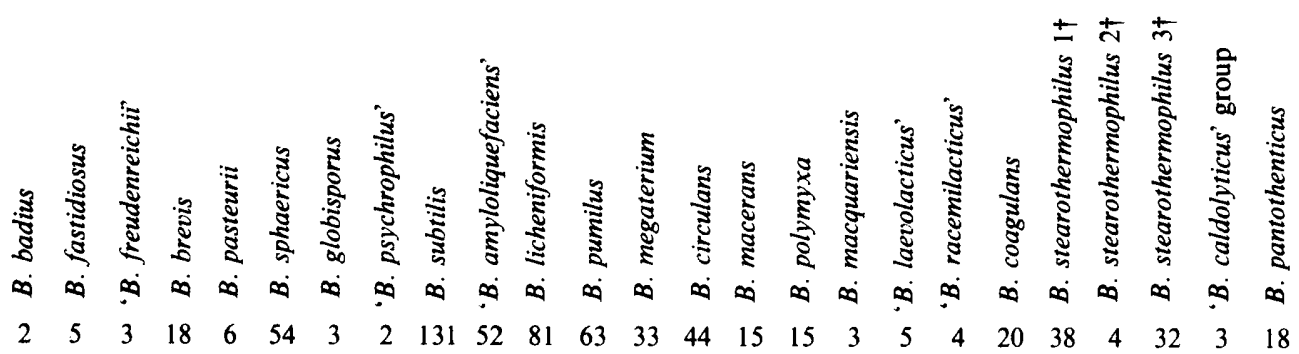

\begin{tabular}{|c|c|c|c|c|c|c|c|c|c|c|c|c|c|c|c|c|c|c|}
\hline \multicolumn{19}{|c|}{ Tests } \\
\hline 45. & & & & 88 & 88 & 95 & 17 & 54 & 25 & 73 & & & 100 & 100 & 35 & 21100 & 9 & 78 \\
\hline 46. & & & & & & & 92 & 6 & 18 & 100 & 40 & 67 & 80 & 100 & 20 & & 44 & \\
\hline 47. & & & & 99 & 98 & 100 & 55 & 60 & 95 & 100 & 100 & 100 & 100 & 100 & 85 & 60100 & $87 \quad 100$ & 100 \\
\hline 48. & & 54 & 33100 & 22 & 19 & 89 & 100 & 97 & 79 & 20 & 20 & 100 & 100 & 100 & 95 & 47 & 6 & 100 \\
\hline 49. & & & & 99 & 100 & 100 & 97 & 100 & 98 & 100 & 100 & 100 & 100 & 100 & 70 & 18100 & 16 & 100 \\
\hline 50. & & & & 100 & 100 & 100 & 100 & 100 & 98 & 100 & 100 & 100 & 100 & 100 & 65 & 55100 & 367 & 100 \\
\hline 51. & 16 & 2 & 33 & 100 & 100 & 100 & 100 & 100 & 100 & 100 & 100 & 100 & & 75 & 95 & 76100 & $22 \quad 100$ & 100 \\
\hline 52. & & & & 100 & 100 & 100 & 100 & 100 & 100 & 100 & 100 & 100 & 100 & 100 & 65 & 71100 & $\begin{array}{ll}34 & 100\end{array}$ & 100 \\
\hline 53. & & & & 100 & 100 & 100 & 100 & 100 & 98 & 100 & 100 & 100 & 100 & 100 & 70 & 63100 & 37100 & 94 \\
\hline 54. & 5 & 4 & & 100 & 98 & 100 & 46 & 100 & 100 & 100 & 100 & 100 & 100 & 100 & 100 & 100100 & 93100 & 100 \\
\hline 55. & & & & 49 & 84 & 89 & 76 & 100 & 100 & 100 & 100 & 100 & 100 & 100 & 85 & 1325 & 50 & 50 \\
\hline 56. & & & & 80 & 56 & 45 & 23 & 100 & 100 & 100 & 100 & 100 & 100 & 100 & 90 & 58 & $\begin{array}{lll}87 & 100\end{array}$ & 5 \\
\hline 57. & & & & 100 & 100 & 100 & 100 & 100 & 98 & 100 & 100 & 67 & 100 & 100 & 85 & 97100 & 100100 & 89 \\
\hline 58. & & 4 & & 100 & 82 & 100 & 100 & 100 & 98 & 100 & 100 & 100 & 100 & 100 & 100 & 97100 & $90 \quad 100$ & 100 \\
\hline 59. & & & & 83 & 11 & 68 & 1 & 85 & 70 & 100 & 87 & & 100 & 75 & 5 & & & \\
\hline 60. & & & & & & 1 & & 69 & 52 & 100 & 40 & & 100 & 75 & 5 & 81 & $5 \quad 100 \quad 100$ & \\
\hline 61. & & & & 90 & 92 & 79 & 89 & 100 & 98 & 100 & 100 & 100 & 100 & 100 & 95 & 60 & $97 \quad 100$ & \\
\hline 62. & 5 & 4 & & 98 & 98 & 99 & & 100 & 95 & 100 & 100 & 100 & 100 & 100 & 95 & 89 & 100100 & 100 \\
\hline 63. & 5 & & & 98 & 94 & 96 & & 100 & 93 & 100 & 100 & 100 & 60 & 50 & 35 & 47 & $90 \quad 100$ & 17 \\
\hline 64. & 5 & & & & & 1 & & 30 & 4 & & & & & & & 3100 & & \\
\hline 65. & & & & 96 & 88 & 89 & 100 & 97 & 98 & 1001 & 100 & 100 & & 25 & 70 & 37100 & 56100 & 55 \\
\hline 66. & & & & 97 & 791 & 100 & 54 & 100 & 100 & 100 & 100 & 100 & 100 & 75 & 95 & 95100 & 100100 & 100 \\
\hline 67. & & & & & & & & & & & 7 & & 60 & 75 & & & & \\
\hline 68. & & & 100 & & & 96 & 65 & 3 & 2 & & & & 100 & 50 & 45 & 79 & 87100 & 100 \\
\hline 69. & & & & & & & & 3 & & & & & & 25 & & & & \\
\hline 70. & & & & & & & & 3 & 43 & 87 & & & & & & 100 & & 78 \\
\hline 71. & & & & & & & & 60 & 7 & 80 & 7 & & & 25 & 55 & 100 & & \\
\hline 72. & & & & & & & & & & & 7 & & & & & 3 & & \\
\hline 73. & & & & 4 & & 2 & & 15 & 61 & 93 & 80 & 67 & & 50 & 75 & & & 72 \\
\hline 74. & & & & & & & & & 2 & & & & 20 & & 30 & & & \\
\hline 75. & & & & 2 & & & & 6 & 79 & 93 & 53 & & 60 & 50 & 55 & 89100 & 100 & \\
\hline
\end{tabular}

* Bacillus cereus strains isolated in connection with outbreaks of emetic-type food poisoning and strains of serotypes 1, 3, 5 and 8 commonly associated with such outbreaks.

$\dagger$ Groups 1 to 3 of Walker \& Wolf (1971).

$\ddagger$ Mean cell width for strains studied.

\section{Bacillus firmus and B. lentus}

A spectrum-like arrangement of strains of $B$. firmus, B. lentus and pigmented isolates (SM strains) from salt marsh and sea water (Turner \& Jervis, 1968) was observed by Gordon et al. (1977) and discussed by Logan \& Berkeley (1981). The species results in Table 1 incorporate results of tests on the SM strains; these were allocated to the species to which they showed greatest similarity. The great within-species and between-species variation of $B$. firmus and $B$. lentus and the extent to which they have common characters is evident in the results shown, but 
differentiation is possible because $B$. lentus strains produce acid from a wider range of carbohydrates.

\section{Bacillus laterosporus}

This is a species with highly characteristic biochemical and morphological features and the strains examined showed little variation.

\section{Bacillus alvei and 'B. thiaminolyticus'}

Although the results shown in Table 1 suggest some similarity between the two groups and only a few strains of each have been studied, it is clear that they may be separated easily using API tests. As Gibson \& Gordon (1974) point out, more strains of these organisms need to be studied.

\section{'Bacillus carotarum'}

Considerable between-strain variation is seen in this group and its homogeneity is in doubt. Logan (1980) and Logan \& Berkeley (1981) found 'B. carotarum' to exist as a series or spectrum of strains and Gibson (1935) observed considerable morphological variation in strains allocated to this species. Several of the strains studied were received as $B$. megaterium or $B$. cereus $-B$. megaterium intermediates and came from the N. R. Smith collection. Smith et al. $(1946,1952)$ regarded ' $B$. carotarum' as a synonym of $B$. megaterium but this was rejected by Gibson \& Gordon (1974), whose decision was supported by Bonde (1973, 1975), Hunger \& Claus (1978, 1981), Logan (1980) and Logan \& Berkeley (1981). None of the strains studied in the present work showed appreciable similarity to $B$. cereus or $B$. megaterium.

Mesophilic species showing little or no acid production from carbohydrates

The species B. badius, B. fastidiosus, 'B. freudenreichii', B. brevis, B. pasteurii and B. sphaericus all produce little or no acid from carbohydrates and the few positive results gained from tests in the API 50CHB strips are of little importance in differentiation. The patterns of results given in the API 20E strip, the characteristic vegetative cell and sporangial morphologies, and the special media requirements of certain species (B. fastidiosus and B. pasteurii) make separation simple.

\section{Psychrophilic species}

Of the five psychrophilic groups considered ('B. psychrosaccharolyticus', B. insolitus, $B$. globisporus, ' $B$. psychrophilus' and $B$. macquariensis), none is represented by more than three strains; the results shown are, therefore, of limited value in identification. Within-species variation is low, except in the case of $B$. insolitus, and the patterns of results are individual enough to support the status of each species.

\section{The Bacillus subtilis group and B. megaterium}

The B. subtilis spectrum or group as defined by Gibson (1944) and Gordon et al. (1973) comprises $B$. subtilis, $B$. pumilus and $B$. licheniformis. To this may be added ' $B$. amyloliquefaciens' which was regarded by Gordon et al. (1973) as a synonym of $B$. subtilis, a position formalized in the Approved Lists (Skerman et al., 1980). Logan (1980) and Logan \& Berkeley (1981) found that $B$. megaterium clustered with the $B$. subtilis group and so it too is considered here.

O'Donnell et al. (1980) studied eight strains of each of the four species comprising the $B$. subtilis group and found that they could separate $B$. subtilis, B. pumilus, $B$. licheniformis and ' $B$. amyloliquefaciens' using API tests, DNA reassociation studies and pyrolysis gas liquid chromatography but that ' $B$. amyloliquefaciens' could not be separated from $B$. subtilis when the classical tests of Gordon et al. (1973) were used. Study of a larger number of strains by Logan (1980) and Logan \& Berkeley (1981) revealed the presence of intermediate strains which obscured the distinction so that the species cannot now be clearly separated using the API tests. Only two tests in Table 1, acid production from inulin, and chains of cells, are of value in separating the two species. 
The separation of the other species presents no difficulty, despite appreciable within-species variation.

\section{Bacillus circulans, B. macerans and B. polymyxa}

Gibson \& Topping (1938) found $B$. circulans to be a species complex and later workers have endorsed this description (Logan \& Berkeley, 1981). The results summarized in Table 1 for the 44 strains of this species studied indicate great between-strain variation. The pattern of reactions is, however, individual enough to enable $B$. circulans to be separated from the two closely related species B. macerans and B. polymyxa. Logan (1980) and Logan \& Berkeley (1981) found $B$. macerans to be so closely related to $B$. circulans and $B$. polymyxa that it lay between and almost joined them in principal co-ordinate plots.

\section{Bacillus coagulans, 'B. laevolacticus' and 'B. racemilacticus'}

The species $B$. coagulans forms a very diffuse group showing great variation between strains so that a species pattern of reactions is difficult to define. Other authors have also found the species to be heterogeneous (Logan \& Berkeley, 1981). 'Bacillus laevolacticus' and 'B. racemilacticus' were originally separated mainly on the basis of the isomer, or isomers, of lactic acid produced by glucose fermentation (Gibson \& Gordon, 1974); their similarity is clear from the results, albeit of few strains, shown in Table 1, but separation is possible. The close relationship of these two species to $B$. coagulans is also clear but, again, differentiation is possible.

\section{Bacillus stearothermophilus and the ' $B$. caldolyticus' group}

The results of Logan (1980) and Logan \& Berkeley (1981) supported the division of $B$. stearothermophilus into the three groups proposed by Walker \& Wolf (1971); the results given for $B$. stearothermophilus in Table 1 are divided into the three groups accordingly. Group 1 is represented by only four strains but appears fairly homogeneous. Although groups 1 and 3 are heterogeneous (Walker $\&$ Wolf subdivided these groups) and there are few tests available for differentiation each has a characteristic pattern of results. It is possible that further study will show that the members of these groups represent a discontinuous series or spectrum.

The species ' $B$. caldolyticus', 'B. caldotenax' and ' $B$. caldovelox' (Heinen \& Heinen, 1972), each represented by a single strain, show great similarity and a close relationship to $B$. stearothermophilus group 3.

\section{Bacillus pantothenticus}

In the analyses of Logan (1980) and Logan \& Berkeley (1981) this species showed phenotypic relatedness to $B$. coagulans and B. stearothermophilus; it is, however, a homogeneous species with characteristic morphological and biochemical properties that allow it to be differentiated from these two species with ease.

\section{Other species}

The foregoing covers 26 of the 31 Bacillus species included in the Approved Lists of Bacterial Names (Skerman et al., 1980). The remaining five species are $B$. larvae, B. lentimorbus, $B$. popilliae, $B$. alcalophilus and $B$. acidocaldarius; the first three of these are fastidious and require special growth media and conditions that are more easily supplied in the classical test procedures. Bacillus alcalophilus and B. acidocaldarius require very high and very low $\mathrm{pH}$, respectively, for growth and are not, therefore, compatible with the narrow $\mathrm{pH}$ ranges of the media in API strips. These organisms may, however, be identified satisfactorily by the nature of their requirements for growth.

A taxon-radius model type of identification system, for use with a computer, is easily constructed from a table of per cent positive results (Sneath, 1978b). The method assumes, however, that the taxa are roughly hyperspherical and that intermediate forms are relatively uncommon; the model breaks down if there is considerable overlap of hyperspheres (Sneath \& Sokal, 1973) but this would indicate the need for, and may be remedied by, reclassification. Clearly, the spectra and species complexes occurring in Bacillus (B. firmus, B. lentus and B. 
circulans for example) cannot be regarded as hyperspherical and appreciable overlap of taxa occurs. Furthermore, a minimum of ten strains should be used for each taxon in such systems (Sneath, 1978 $b$ ) and several of the taxa in the present work do not satisfy this requirement.

Discriminant analysis is an extension of the taxon-radius model method and gives reliable identification with groups that show partial overlap in their properties; it achieves this by weighted transformation of character axes so that average within-taxon scatter is standardized, and by altering angles between character axes to make clusters as hyperspherical as possible. This advantage over the taxon-radius model, however, is counteracted by the method requiring the taxa to be few in number, the clusters to be of similar size, shape and orientation, and the unknown to belong to one of the taxa included (Sneath \& Sokal, 1973; Sneath, 1978b). The first and last of these problems are substantially overcome by the use of the generalized distance function $D^{2}$ (Mahalanobis, 1936; Sneath \& Sokal, 1973) which is used in canonical variates analysis. Such methods, however, have limited application; large numbers of individuals are required in each taxon but the gain in discrimination over simpler methods may be slight (Sneath \& Sokal, 1973).

A large number of taxa are considered in the present work; this, taken with the inadequate representation of some of these taxa, argues against the use of discriminant analysis. On the other hand, the difficulties of separating several of the groups and the high degree of phenetic overlapping that occurs with such polythetic taxa make sequential methods, such as dichotomous keys and polyclaves, inappropriate (Sneath \& Sokal, 1973).

It may be concluded, therefore, that simultaneous methods such as the use of diagnostic tables, identification by similarity coefficients, and, for the clearly defined and adequately represented taxa, taxon-radius models are most suited to the task of identifying members of the genus Bacillus.

Other identification schemes for Bacillus such as those of Gibson \& Topping (1938), Smith et al. (1946, 1952), Wolf \& Barker (1968), Gordon (1973), and Gordon et al. (1973), based upon dichotomous keys, and those of Cowan \& Steel $(1965,1974)$ based upon tables, do not allow the identification of so many species as the system described here and usually do not permit the identification of atypical and intermediate strains. The keys of Gordon et al., (1973) and Bonde (1978, and personal communication) for example, use 27 and 22 characters and recognize only 21 and 10 taxa respectively. The computer-assisted identification system described by WillemseCollinet et al. (1980), and based upon studies of 30 strains from culture collections, used 24 tests, taking up to $7 \mathrm{~d}$ for the identification of only 18 species, and was unable to achieve a satisfactory diagnosis in several instances, although misidentification did not occur. Our results enable the recognition of 38 taxa and the availability of results for a large number of tests (Table 1) allows the identification of atypical and intermediate strains. Establishment of the validities of some of the taxa recognized awaits the results from studies on more strains and of further information from other sources. The system does, however, make possible the diagnosis of 26 of the 31 Bacillus species included in the Approved Lists of Bacterial Names (Skerman et al., 1980).

\section{REFERENCES}

Bonde, G. J. (1973). The Genus Bacillus. An Examination of 460 Mesophilic Strains. Research Council series no. 2. Copenhagen: International Service System.

BoNDE, G. J. (1975). The genus Bacillus. An experiment with cluster analysis. Danish Medical Bulletin 22, $41-61$.

BoNDE, G. J. (1978). Current status of Bacillus classification. Abstracts of the XII International Congress of Microbiology, p. 86. München: International Association of Microbiology Societies.

Cohen-Bazire, G., Sistrom, W. R. \& Stanier, R. Y. (1957). Kinetic studies of pigment synthesis by nonsulfur purple bacteria. Journal of Cellular and Comparative Physiology 49, 25-68.
Cowan, S. T. \& STeEL, K. J. (1965). Identification of Medical Bacteria. Cambridge: Cambridge University Press.

Cowan, S. T. \& STEeL, K. J. (1974). Identification of Medical Bacteria, 2nd edn. Cambridge: Cambridge University Press.

Deutsche Sammlung von Mikroorganismen (1977). Catalogue of Strains, 2nd edn, p. 276. Edited by D. Claus \& C. Schaab-Engels. München: Gesellschaft für Strahlen und Umweltforschung $\mathrm{mbH}$.

GiBson, T. (1935). The urea-decomposing microflora of soils I. Description and classification of the organisms. Zentralblatt für Bakteriologie, Parasitenkunde, Infektionskrankheiten und Hygiene, Abt. II 92, 364-380. 
Gibson, T. (1944). A study of Bacillus subtilis and related organisms. Journal of Dairy Research 13, 248260.

Gibson, T. \& GoRdon, R. E. (1974). Bacillus. In Bergey's Manual of Determinative Bacteriology, 8th edn, pp. 529-550. Edited by R. E. Buchanan \& N. E. Gibbons. Baltimore: Williams \& Wilkins.

Grbson, T. \& ToppING, L. E. (1938). Further studies of the aerobic sporeforming bacilli. Proceedings, Society of Agricultural Bacteriologists, 43-44.

Gilbert, R. J. \& PARRY, J. M. (1977). Serotypes of Bacillus cereus from outbreaks of food poisoning and from routine foods. Journal of Hygiene 78, 69-74.

Gilbert, R. J., Turnbull, P. C. B., Parry, J. M. \& KRAMER, J. M. (1981). Food poisoning and other clinical infections associated with Bacillus species with particular reference to $B$. cereus. In The Aerobic Endospore-forming Bacteria: Classification and Identification, pp. 297-314. Edited by R. C. W. Berkeley \& M. Goodfellow. London: Academic Press.

GoRdON, R. E. (1973). The genus Bacillus. In Handbook of Microbiology, vol. 1, Organismic Microbiology, pp. 71-88. Edited by A. I. Laskin \& H. A. Lechevalier. Cleveland: The Chemical Rubber Co. Press.

GORDON, R. E. (1981). One hundred and seven years with the genus Bacillus. In The Aerobic Endosporeforming Bacteria: Classification and Identification, pp. 1-15. Edited by R. C. W. Berkeley \& M. Goodfellow. London: Academic Press.

Gordon, R. E., Haynes, W. C. \& Pang, C. H.-N. (1973). The Genus Bacillus. Washington, DC: United States Department of Agriculture.

Gordon, R. E., Hyde, J. L. \& Moore, J. A. (1977). Bacillus firmus-Bacillus lentus: a series or one species? International Journal of Systematic Bacteriology 27, 256-262.

Gower, J. C. (1968). Adding a point to vector diagrams in multivariate analysis. Biometrika $\mathbf{5 5}$, $582-585$.

Gower, J. C. (1971). A general coefficient of similarity and some of its properties. Biometrics 27, 857-874.

GreEN, D. M. (1975). Anthrax bacillus. In Medical Microbiology, 12th edn, vol. 2, pp. 449-453. Edited by R. Cruickshank, J. P. Duguid, B. P. Marmion \& R. H. A. Swain. Edinburgh, London \& New York: Churchill Livingstone.

Heinen, U. J. \& Heinen, W. (1972). Characteristics and properties of a caldoactive bacterium producing extracellular enzymes and two related strains. Archiv für Mikrobiologie 82, 1-23.

HUNGer, W. \& ClaUS, D. (1978). Bacillus megaterium: A species complex. Abstracts of the XII International Congress of Microbiology, p. 87. München: International Association of Microbiology Societies.

Hunger, W. \& Claus, D. (1981). Taxonomic studies on Bacillus megaterium and on agarolytic Bacillus strains. In The Aerobic Endospore-forming Bacteria: Classification and Identification, pp. 217-239. Edited by R. C. W. Berkeley \& M. Goodfellow. London: Academic Press.

KING, A. \& PhIllips, I. (1978). The identification of pseudomonads and related bacteria in a clinical laboratory. Journal of Medical Microbiology 11, 165176.
Logan, N. A. (1980). Studies on the taxonomy and identification of members of the genus Bacillus: application of miniaturized, standardized, commercially available test systems. $\mathrm{PhD}$ thesis, University of Bristol.

Logan, N. A. \& Berkeley, R. C. W. (1981). Classification and identification of members of the genus Bacillus using API tests. In The Aerobic Endospore-forming Bacteria: Classification and Identification, pp. 105-140. Edited by R. C. W. Berkeley \& M. Goodfellow. London: Academic Press.

Logan, N. A., CAPel, B. J., Melling, J. \& Berkeley, R. C. W. (1979). Distinction between emetic and other strains of Bacillus cereus using the API system and numerical methods. FEMS Microbiology Letters 5, 373-375.

MCFARLAND, J. (1907). The nephelometer. Journal of the American Medical Association 49, 1176-1178.

MaHALANOBIS, P. C. (1936). On the generalized distance in statistics. Proceedings of the National Institute of Sciences of India 2, 49-55.

O'Donnell, A. G., Norris, J. R., Berkeley, R. C. W., Claus, D., Kaneko, T., Logan, N. A. \& NozAKI, R. (1980). Characterization of Bacillus subtilis, Bacillus pumilus, Bacillus licheniformis and Bacillus amyloliquefaciens by pyrolysis gas-liquid chromatography, deoxyribonucleic acid-deoxyribonucleic acid hybridization, biochemical tests and API systems. International Journal of Systematic Bacteriology 30, 448-459.

PRIEST, F. G. (1981). DNA homology in the genus Bacillus. In The Aerobic Endospore-forming Bacteria: Classification and Identification, pp. 33-57. Edited by R. C. W. Berkeley \& M. Goodfellow. London: Academic Press.

QUESNEL, L. B. (1971). Microscopy and micrometry. Methods in Microbiology 5A, 1-103.

Ross, G. J. S. (1975). Rapid techniques for automatic identification. In Biological Identification with Computers, pp. 93-102. Edited by R. J. Pankhurst. London \& New York: Academic Press.

Skerman, V. B. D., McGowan, V. \& SNeath, P. H. A. (1980). Approved lists of bacterial names. International Journal of Systematic Bacteriology 30, 225420.

Smith, N. R., Gordon, R. E. \& ClaRK, F. E. (1946). Aerobic Mesophilic Sporeforming Bacteria. Miscellaneous Publication no. 559. Washington, DC: United States Department of Agriculture.

SMITH, N. R., Gordon, R. E. \& ClaRK, F. E. (1952). Aerobic Sporeforming Bacteria. Monograph no. 16. Washington, DC: United States Department of Agriculture.

SNEATH, P. H. A. (1974). Test reproducibility in relation to identification. International Journal of Systematic Bacteriology 24, 508-523.

SNEATH, P. H. A. (1978a). Classification of microorganisms. In Essays in Microbiology, pp. 9/1-9/31. Edited by J. R. Norris \& M. H. Richmond. Chichester: John Wiley.

SNEATH, P. H. A. (1978b). Identification of microorganisms. In Essays in Microbiology, pp. 10/110/32. Edited by J. R. Norris \& M. H. Richmond. Chichester: John Wiley.

SNEATH, P. H. A. \& Collins, V. G. (1974). A study in test reproducibility between laboratories: report of a 
Pseudomonas working party. Antonie van Leeuwenhoek 40, 481-527.

SNeath, P. H. A. \& Sokal, R. R. (1973). Numerical Taxonomy. San Francisco: W. H. Freeman.

SOKAL, R. R. \& MiChenER, C. D. (1958). A statistical method for evaluating systematic relationships. University of Kansas Science Bulletin 44, 467-507.

TAYLOR, A. J. \& GILBERT, R. J. (1975). Bacillus cereus food poisoning: a provisional serotyping scheme. Journal of Medical Microbiology 8, 543-550.

TURNER, M. \& JeRVIS, D. I. (1968). The distribution of pigmented Bacillus species in saltmarsh and other saline and non-saline soils. Nova Hedwigia 16, 293297.
WALkeR, P. D. \& Wolf, J. (1971). Taxonomy of Bacillus stearothermophilus. In Spore Research 1971, pp. 247-262. Edited by A. N. Barker, G. W. Gould \& J. Wolf. London \& New York: Academic Press. Willemse-Collinet, M. F., Tromp, Th. F. J. \& HuizingA, T. (1980). A simple and rapid computerassisted technique for the identification of some selected Bacillus species using biochemical tests. Journal of Applied Bacteriology 49, 385-393.

WOLF, J. \& BARKER, A. N. (1968). The genus Bacillus: aids to the identification of its species. In Identification Methods for Microbiologists, part B, pp. 93-109. Edited by B. M. Gibbs \& D. A. Shapton. London: Academic Press. 